Danuta Zawadzka

Department of Finance

Koszalin University of Technology, Poland

\title{
TRADE CREDIT RISK IN THE BUSINESS OF AGRICULTURAL ENTERPRISES IN THE MIDDLE POMERANIA REGION
}

\begin{abstract}
The aim of the research presented in this article is to assess the risks associated with granting trade credit at a group of agricultural enterprises on the example of businesses located in Middle Pomerania. This assessment of the risk involved in extending credit to business partners in the agricultural sector was conducted in stages. The first task was to describe the sample of farms, with particular emphasis placed on the effects of their financial decisions. This was followed by a presentation of the activity of agricultural holdings in respect of the granting of trade credit, whose main aims were to evaluate the tendency to postpone the maturity dates of customer payments and to assess the characteristics of price discount policies. Counterparties' credit risk was measured as the proportion of total sales revenue lost by agricultural businesses due to non-repayment of trade credit.
\end{abstract}

Keywords: trade credit, risk, agricultural enterprises, Middle Pomerania.

\section{Introduction}

Trade credit involves deferring the payment date for goods and services in transactions carried out between companies. It is a loan granted by a supplier to a customer in connection with the sale of goods and services (the trade receivables of the supplier) and a source of short-term funding for current product requirements (the commercial obligation of the customer) (Zawadzka 2009). The factors that shape the demand for trade credit, which depends in general terms on the operational specifics of the company concerned, include financial motives, transactional motives, the buyers' desire to check the quality of products, and the wish to secure financial 
benefits. High operational risk, which is mainly due to the long production cycle, the dependence of agricultural production on natural factors, high capital intensity in relation to the sales-revenue volumes and money surpluses generated (the average farm is involved in small-scale production), low asset elasticity (high share of land in total resources), little capacity to accumulate equity, and a weak relationship with the market, are among the specific features of agriculture as a business.

The aim of the research presented in this article is to assess the risks associated with granting trade credit at a group of agricultural enterprises on the example of businesses located in Middle Pomerania ${ }^{1}$.

This assessment of the risk involved in extending credit to business partners in the agricultural sector was conducted in stages. The first task was to describe the sample of farms, with particular emphasis placed on the effects of their financial decisions. This was followed by a presentation of the activity of agricultural holdings in respect of the granting of trade credit, whose main aims were to evaluate the tendency to postpone the maturity dates of customer payments and to assess the characteristics of price discount policies. Counterparties' credit risk was measured as the proportion of total sales revenue lost by agricultural businesses due to non-repayment of trade credit.

\section{Literature}

There is lively discussion in the literature on the factors influencing the choice of credit in the financial decision-making of businesses, including those involved in farming. The relevant research areas in the field of financing for this particular group of entities can be summarised as follows: 1) linking agricultural enterprises with the institutional environment (Grzelak 2008; Kata 2011a; Kulawik 2003; Kulawik 2008; Czyżewski \& Matuszczak 2009); 2) linking financial decisions with farmers' investment decisions (Kata 2011b; Wasilewski \& Mądra 2009; Franc-Dąbrowska 2010; Bereżnicka 2009); 3) credit constraints in agriculture, especially the problem of asymmetric information in the agricultural credit market (Daniłowska 2008; Kata 2010a; Kulawik 2003; Kulawik 2008; Swinnen \& Gow 1999; Petrick 2004); 4) the use of credit subsidies (Rosa 2011; Czerwińska-Kayzer 2002); 5) the importance of cooperative banks in lending to farmers

${ }^{1}$ The study was conducted within the framework of a project funded by the National Science Centre, which was entitled "Growth and allocation of financial and tangible assets of Middle Pomerania farmers (agricultural enterprises and households)" (contract No. 3577/B/H03/2011/40). 
(Szambelańczyk 2006; Siudek 2008; Rosa 2012). The questions explored in this article, which are framed to investigate short-term decisions and limited access to credit from institutional sources, come under the third of the five research areas identified above. Contemporary studies have found that the use of trade credit is a consequence of market imperfections stemming from asymmetric information and transaction costs (e.g. Kata 2010a). When enterprises' access to capital from financial institutions is restricted, they seek substitute funding in the form of the trade credit extended by suppliers.

The risks associated with granting trade credit involve the possibility that customers will default on their liabilities for goods or services. This occurs when there is no payment at all, when the value of the payment is other than expected or when it is delayed (Zawadzka 2008a). From the point of view of suppliers granting credit to customers, the risk is mainly associated with delays in invoice payments and with the subsequent cases of customer insolvency and bankruptcy. The risk for the contractor is directly affected by the risks of transactions in the broader sense, which is a matter of the nature of the transaction that is the subject of the economic activity. From the supplier's point of view, there are several factors that may be distinguished in the risk category: a) the risk of the subject of the transaction: the amount of processing the goods require affects the method chosen to secure transactions and the length of time for which trade credit is extended; the less the goods are processed, the lower the risk to the supplier; b) the risks associated with the attitude of the recipient to the regulation of trade payables, which refers to any opportunistic tendencies of the debtor that may be detrimental to the supplier; c) the financial risk of the counterparty, which has an impact on the availability of alternative sources of financing for current supply and affects the ability to repay debt according to the terms agreed for granting trade credit; d) liquidity risk of the counterparty, which depends on the timely payment of liabilities arising from the supply of goods or services; e) counterparty default risk, which refers to gauging whether a counterparty has any capacity at all to repay a trade credit debt; f) risks relating to the type of settlement which is used in the transaction; g) risks relating to the type of security (Zawadzka 2010). By contrast, the risk the recipient accepts arises from possible delays in the delivery of goods and services and the likely reduction in the quality of the product offer of the counterparty (commodity risk).

This paper tackles the problem from the perspective of the provider risk, and the related payment risk, of the counterparty. The terms of mutual settlements between businesses depend on numerous factors (Zawadzka 
\& Ardan 2009). They take the forms they do prompted by the particular needs of turnover and the financial capacity of the parties to commercial transactions (Zawadzka 2007a, 2007b). The question of payment risk as an aspect of the operational risk arising from the use of trade credit in the agricultural sector is one that has been addressed comparatively rarely in the literature. Franc-Dąbrowska (2010), for example, has demonstrated that payment delays are felt particularly keenly in the agricultural sector and that the increasing share of receivables is partly due to delayed customer payments and partly to the decreasing scale of sales revenue. This situation is made worse where there is a simultaneous increase in the market prices of agricultural inputs and decrease in demand for agricultural products. Companies that are involved in purchasing agricultural products, for example, then have a problem meeting their current obligations, which results in an escalation of the payment gridlock (Wielicki \& Baum 2010).

Because agricultural companies are both the providers and recipients of trade credit, they must take into account the risks arising from its use when taking financial and investment decisions. The share of short-term liabilities for supplies and services in the current liabilities of agricultural enterprises in Poland at the end of 2011 amounted to 40.4\% (GUS 2012). By way of comparison, the share of loans and short-term borrowing in current liabilities for the same period was $20.2 \%$. Within the context of short-term financial decisions, it is trade credit, in the form of liabilities to suppliers of goods and services, that dominates the financing of current supply at agricultural enterprises. In determining the credit position of agricultural enterprises in Poland in the years 2006-11 (GUS 2007; 2008; 2009; 2010; 2011; 2012), it should be noted that these entities were more often the providers of trade credit than its recipients. Except for 2008, the value of trade receivables was more than twice that of the value of liabilities from deliveries and services. This was reflected in the credit position indicator, which showed an upward trend over the period of the analysis.

\section{Data Sources and Research Methods}

The target population was farms in the region of Middle Pomerania, which was chosen for its dominant agricultural function. The study was designed both to be representative of the region and to contribute to the discussion on risk assessment in agriculture. The definition of an enterprise adopted for the enquiry was that of a distinct legal, organisational and economic entity producing and selling agricultural products or providing 
production services for agriculture (Ziętara 2009). Given the diversity of the research sample and the consequences for the risk assessment of credit received or provided by agricultural contractors, the analysis distinguished between commercial farms, who were assumed to be agricultural enterprises selling to the market, and subsistence farms producing mainly for household needs. Middle Pomerania, which has no separate public statistics classification, covers the area of the former provinces of Koszalin and Słupsk (Zawadzka 2008b) and includes 15 counties and municipalities. For the West Pomeranian province these are Białogard, Drawsko, Kołobrzeg, Koszalin, Sławno, Szczecinek, Świdwin, Wałcz and Koszalin district; for the province of Pomerania these are Bytów, Chojnice, Człuchów, Lębork, Słupsk and Słupsk district. It should be noted that, according to the Central Statistical Office, the counties of Wałcz and Chojnice fall within the Koszalin and Słupsk sub-regions respectively. The data for the analyses were obtained in the course of research conducted using direct survey techniques, which involved 1004 farms in the Middle Pomerania region. The research, which was conducted in May and June 2012 using the direct interview method, returned 933 correctly completed questionnaires $(92.93 \%$ of the surveys distributed). The respondents were asked to provide information for the year 2011. Certain questions, however, related to the years 2004 to 2011. As the aim of the study was to assess the risk involved in extending credit, the study was conducted from the perspective of an agricultural enterprise contractor providing trade credit.

\section{Characteristics of the Sample}

The farms in the sample were diverse. Of those surveyed, $66.88 \%$ were commercial farms, and thus regarded as agricultural enterprises, and $33.12 \%$ (309 farms) were subsistence farms. Of the population studied, $43.52 \%$ had a clear focus on crop production, and $10.61 \%$ raised livestock. The remaining farms declared no major specialisation. The average size of the land holdings was 50.9 ha, but the predominant size of holding was 15 ha. The value of agricultural production in 2011 at a little over half of the farms, 55.31\%, was less than PLN 30,000 (ca. EUR 7143). Only 3.97\% of them recorded a production value for that year of above PLN 500,000. As was stated above, the distinction between commercial and subsistence modes of agricultural production also represents a difference in the context of financial decisions within the sample. In the sample of farms from Middle Pomerania, 471 subjects $(50.48 \%$ of the sample) declared that in 
2004-10 they had benefited from outside sources of financing. By 2011, the proportion of these households had fallen by 4.71 percentage points. The average share of outside capital in the financing structure in 2004-10 was $17.29 \%$. Yet by 2011 this had fallen by 2.05 percentage points. Thirty-one per cent of the entities declared that they had used both deferred payment dates and supplier discounts in 2011. By comparison, $14.47 \%$ of the surveyed farms declared they had used commercial loans to finance agricultural activities in 2004-10. By 2011, this proportion had fallen by 1.61 percentage points. Owners of commercial farms reported increased use of outside capital when compared with those producing for their own needs. Of the former, $56.09 \%$ declared the use of outside sources of funding in 2004-10. By 2011, this proportion had fallen to $50 \%$ of the entities analysed. The average declared participation of outside capital in the structure of financing sources was $20.42 \%$ in the period 2004-11 (against $11 \%$ at subsistence farms). In the following year, this proportion fell by 2.85 percentage points (at subsistence farms by 0.47 percentage points). When compared with subsistence farms, commercial farms made more use of trade credit to finance supplies. Approximately $40 \%$ of the commercial farms declared they had taken advantage of payment deferment and discounts offered by suppliers during the period analysed. This has its source in the tighter relationship commercial farms have with the market. Of the subsistence farms, only $12.62 \%$ declared they had used delayed payments in 2011, while $13.92 \%$ reported that they had benefitted from price discounts offered by suppliers in this period. The comparatively lower rates of liabilities from commercial and trade loans among the subsistence farms reflected their looser and less frequent connections with the market and trade. The disparities between the groups in this area were not, however, great. Of the commercial farms, $16.03 \%$ said they had used commercial loans as a source of financing for the years 2004 to 2010, which compared to $14.26 \%$ in 2011 . Of the subsistence farms, $11.3 \%$ said they had used commercial loans as a source of financing for the years 2004 to 2010 , while $10.03 \%$ stated they had done the same in 2011.

The conclusions drawn by analysing data from the farms of Middle Pomerania to some extent confirm the observations in the sectors. First of all, equity was the main source of funding for agricultural activities and, second, a larger number of respondents declared they used trade credit offered by suppliers to a greater extent than bank loans. 


\section{Results and Discussion}

The average share of total sales revenue at agricultural enterprises in Middle Pomerania in 2011 supported by deferred payment (sale with an offer of trade credit) was $35.25 \%$. In the group of commercial farms, where this proportion was higher, half of the sample stated they had financed part of the proceeds from sales with an offer of trade credit of above $50 \%$. The average share of total sales revenue at subsistence farms in Middle Pomerania in 2011 supported by deferred payment (sale with an offer of trade credit) was $9.73 \%$.

Deferral of payments to contractors in 2011 was declared by $51.34 \%$ of the respondents (479 farms), of which $87.26 \%$ were commercial holdings (Fig. 1).

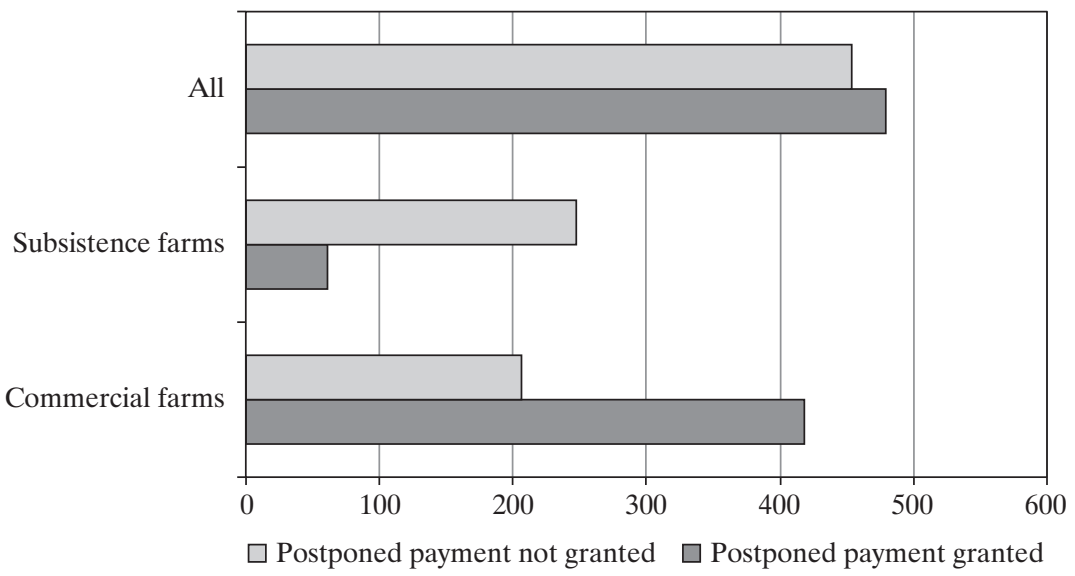

Fig. 1. Numbers of Commercial and Subsistence Farms Postponing Payment to Customers

Source: author's own study based on surveys conducted in the Middle Pomerania region.

The most common deferral period granted was 14 days (Fig. 2), while the most frequent shortest period of trade credit awarded to recipients was 7 days. Compared with commercial farms, subsistence farms were granted more days of deferral in the category of the longest maturity dates. This involved the occasional sale of produce - mainly to family and friends.

A small group of the farms surveyed (9.97\% of the sample) offered discounts to customers, of which $87.1 \%$ (81 farms) were commercial enterprises. This is in accord with their purpose of selling to the market. The most frequent of the highest discounts offered by the farms of Middle 
Pomerania was $10 \%$, while the lowest discount offered was $5 \%$. The former figure was close to the average value of the highest discounts offered $(10.71 \%)$. When considering discounts it was interesting to note how their levels varied according to whether the farms were commercial or subsistence holdings (Fig. 3).

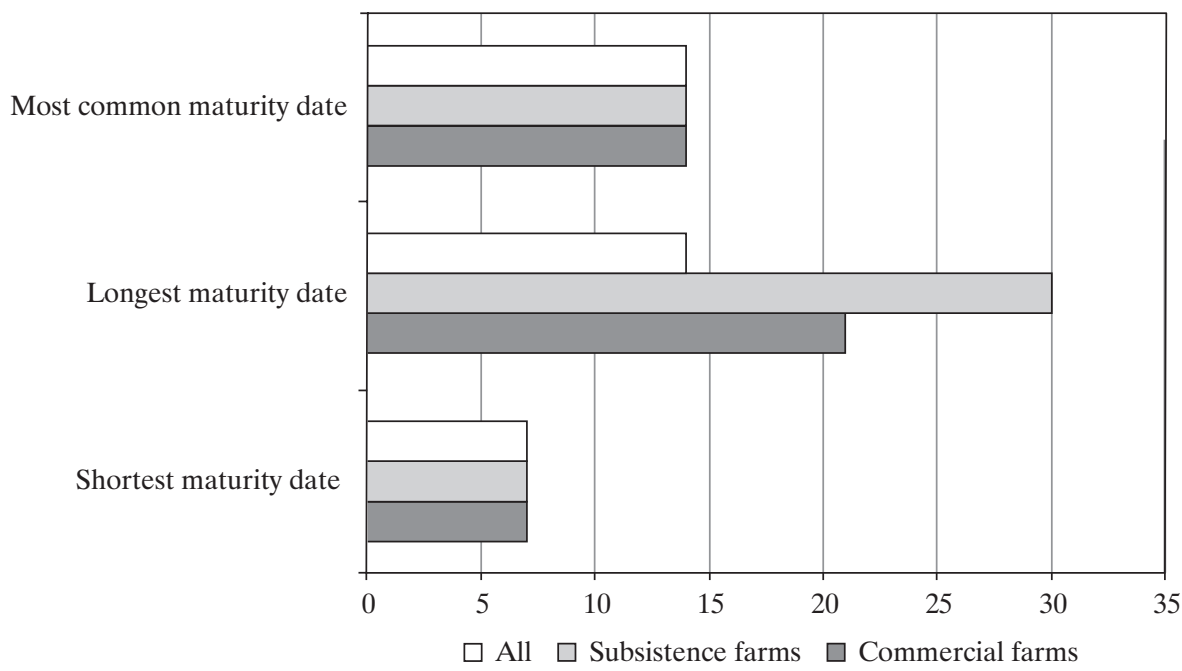

Fig. 2. Length of Trade Credit Granted by Farm Type (Days)

Source: author's own study based on surveys conducted in the Middle Pomerania region.

According to the average and most common values, subsistence farms offered higher price discounts than commodity farms. This was due to the greater frequency of sales on the market cited above. Commercial farms offered contractors higher maximum discounts, which demonstrates their aim of encouraging customers to take advantage of their offer of agricultural products and thus make sales. The highest maximum discount offered in this group of entities in 2011 was $30 \%$.

Fig. 4 presents the risk of trade credit in terms of payments lost due to the failure of counterparties to pay current liabilities. The farmers of Middle Pomerania declared that they had lost only a relatively low proportion of total sales revenue due to non-repayment of liabilities following the granting of trade credit to a recipient.

The farms of Middle Pomerania reported an average loss of $1.94 \%$ of total sales revenue due to delayed payments by customers in 2011 . 


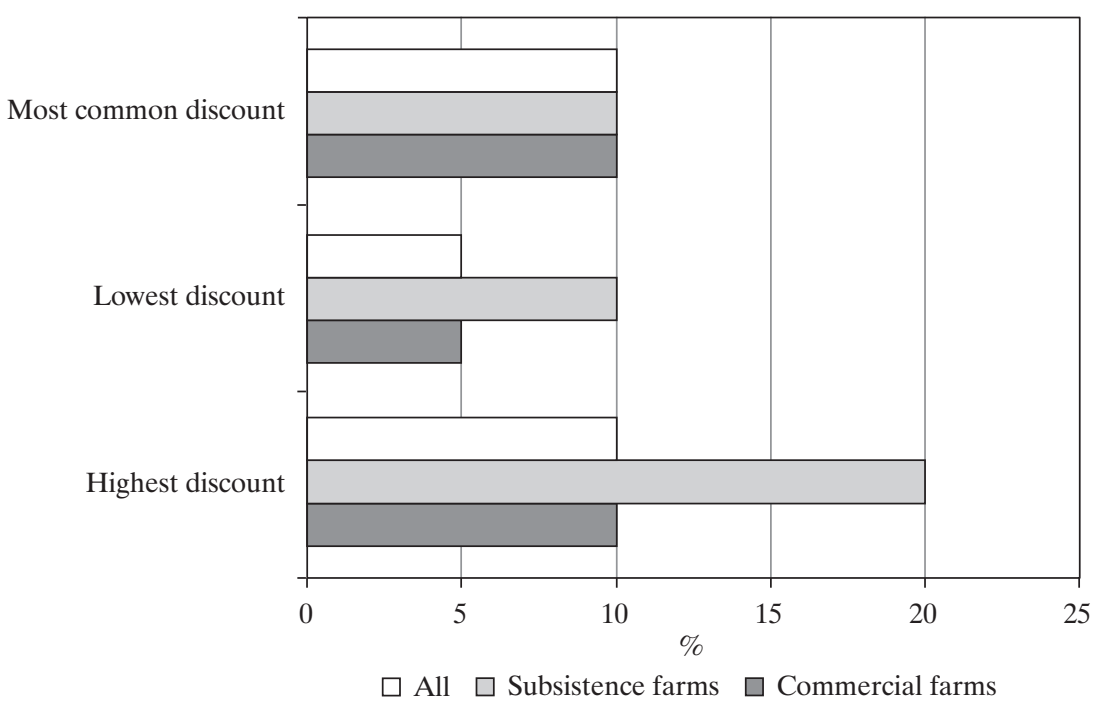

Fig. 3. Discounts Offered to Customers by Farm Type in 2011 (\%)

Source: author's own study based on surveys conducted in the Middle Pomerania region.

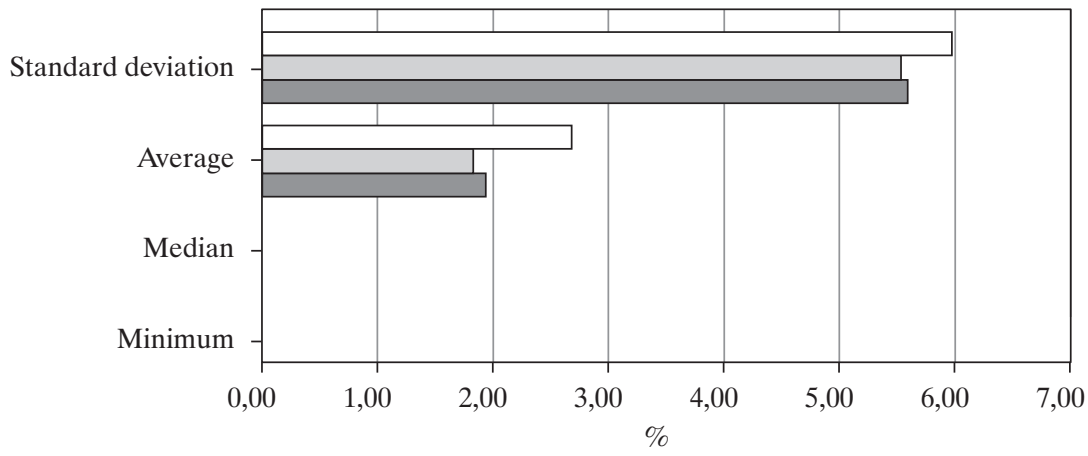

\begin{tabular}{|l|c|c|c|c|}
\cline { 2 - 5 } \multicolumn{1}{c|}{} & Minimum & Median & Average & $\begin{array}{c}\text { Standard } \\
\text { deviation }\end{array}$ \\
\hline$\square$ Subsistence farms & $0,00 \%$ & $0,00 \%$ & $2,68 \%$ & $5,97 \%$ \\
\hline$\square$ Commercial farms & $0,00 \%$ & $0,00 \%$ & $1,83 \%$ & $5,53 \%$ \\
\hline$\square$ All & $0,00 \%$ & $0,00 \%$ & $1,94 \%$ & $5,59 \%$ \\
\hline
\end{tabular}

Fig. 4. Share of Total Sales Lost Due to Non-repayment of Liabilities at Commercial and Subsistence Farms (\%)

Source: author's own study based on surveys conducted in the Middle Pomerania region. 
The majority of farms, however, showed no loss (dominant and median of $0 \%$ ). It was subsistence farms that declared the highest risk of decisions related to the granting of trade credit. It should be emphasised, though, that as these farms consumed their products mainly themselves, rather than sending them to market, they generated a relatively small amount of revenue from the sale of agricultural products.

\section{Conclusions}

This article has presented the results of a risk assessment of the trade credit extended to contractors by agricultural entities. It was assumed for the purposes of the study that commercial farms, whose main purpose is to manufacture products to be sold on the market, can be defined as agricultural enterprises. In terms of financial sources, these farms can be identified by their predominant use of equity. When external short-term finance is required, they tend to turn to trade credit as well as to other sources. The liabilities for credit extended in the commodity market exceeded the value of short-term debt in the financial market. Agricultural companies also used trade credit to boost revenues from sales of manufactured products. Postponement of payment dates in commercial transactions was prevalent in the lending policies of these entities. Payments were most commonly deferred for a period of 14 days following delivery of the products and customers were offered occasional price discounts. The average value of the share of total sales revenues lost by the farms surveyed due to non-repayment of liabilities did not exceed $2 \%$. The risk of granting trade credit should therefore be assessed as low.

\section{Bibliography}

Bereżnicka, J. (2009) "Dźwignia czy maczuga finansowa w realizacji decyzji inwestycyjnych w gospodarstwie rolniczym" [Financial leverage or financial club in the implementation of investment decisions on a farm] in Ekonomika i Organizacja Gospodarki Żywnościowej [The economics and organisation of the food economy]. Academic Papers of the Warsaw University of Life Sciences No. 78. Warsaw: Warsaw University of Life Sciences (SGGW).

Czerwińska-Kayzer, D. (2002) "Kredyt preferencyjny - źródło kapitału w gospodarstwach rolnych" [Preferential loans - a source of capital for farms]. Yearbook of the Poznań University of Life Sciences No. CCCXLIII. Poznań: Poznań University of Life Sciences.

Czyżewski, B. and Matuszczak, A. (2009) "Alokacja zasobów w indywidualnych gospodarstwach rolnych w Polsce w świetle ich związków instytucjonalnych" [The 
allocation of resources in individual farms in Poland in light of their institutional relationships]. Wieś i Rolnictwo 3(144).

Daniłowska, A. (2008) "Asymetria informacyjna i jej przezwyciężanie na rynku kredytów rolniczych" [Information asymmetry and overcoming it on the agricultural credit market]. Life Sciences Yearbooks, Series G, Vol. 95, Nos 3/4.

Franc-Dąbrowska, J. (2010) Teoretyczne i praktyczne aspekty gospodarowania zyskiem $w$ przedsiębiorstwach rolniczych [Theoretical and practical aspects of managing profit in agricultural enterprises]. Warsaw: Warsaw University of Life Sciences (SGGW).

Grzelak, A. (2008) Zwiazki gospodarstw rolnych z rynkiem w Polsce po roku 1990 [The links between farms and the market in Poland after 1990]. Poznań: Poznań University of Economics.

GUS (2007) "Bilansowe wyniki finansowe podmiotów gospodarczych w 2006 roku" [Balance sheet financial performance of business entities in 2006]. Warsaw: Central Statistical Office (GUS).

GUS (2008) "Bilansowe wyniki finansowe podmiotów gospodarczych w 2007 roku" [Balance sheet financial performance of business entities in 2007]. Warsaw: Central Statistical Office (GUS).

GUS (2009) "Bilansowe wyniki finansowe podmiotów gospodarczych w 2008 roku" [Balance sheet financial performance of business entities in 2008]. Warsaw: Central Statistical Office (GUS).

GUS (2010) "Bilansowe wyniki finansowe podmiotów gospodarczych w 2009 roku" [Balance sheet financial performance of business entities in 2009]. Warsaw: Central Statistical Office (GUS).

GUS (2011) "Bilansowe wyniki finansowe podmiotów gospodarczych w 2010 roku" [Balance sheet financial performance of business entities in 2010]. Warsaw: Central Statistical Office (GUS).

GUS (2012) "Bilansowe wyniki finansowe podmiotów gospodarczych w 2011 roku" [Balance sheet financial performance of business entities in 2011]. Warsaw: Central Statistical Office (GUS).

Kata, R. (2010a) "Problem wykorzystania kredytu bankowego w finansowaniu rolnictwa w Polsce i innych krajach Unii Europejskiej" [The problem of the use of bank loans to finance agriculture in Poland and other European Union countries]. Oeconomia 9(3).

Kata, R. (2010b) "Znaczenie banków lokalnych w dostępie rolników do kredytów bankowych" [The importance of local banks in farmer's access to bank loans]. Life Sciences Yearbooks, Series G, Vol. 97.

Kata, R. (2011a) Endogeniczne i instytucjonalne czynniki ksztattujące powiazania finansowe gospodarstw rolnych $z$ bankami [Endogenous and institutional factors affecting the financial links between farms and banks]. Rzeszów: Rzeszów University.

Kata, R. (2011b) "Interwencjonizm kredytowy w rolnictwie a problem dostępu rolników do kredytu bankowego" [Credit intervention in agriculture and the problem of farmers' access to bank loans]. Life Sciences Yearbooks, Series G, Vol. 98.

Kulawik, J. (2003) "Kredytowanie i finansowanie rolnictwa w przededniu integracji z Unią Europejską" [The financing and provision of loans to agriculture on the eve of accession to the European Union], Part II. Bank $i$ Kredyt 6.

Kulawik, J. (2008) "Główne problemy polityki finansowej w rolnictwie polskim" [Key problems of financial policy in Polish agriculture]. Bank $i$ Kredyt 3. 
Petrick, M. (2004) "A Microeconometric Analysis of Credit Rationing in the Polish Farm Sector". European Review of Agricultural Economics, Vol. 31, No. 1, http://dx.doi.org/ 10.1093/erae/31.1.77.

Rosa, A. (2011) "Kredyty preferencyjne jako forma finansowania działalności rolniczej w Polsce" [Preferential loans as a form of financing agricultural activities in Poland] in Ekonomika i Organizacja Gospodarki Żywnościowej [The economics and organisation of the food economy]. Academic Papers of the Warsaw University of Life Sciences No. 91. Warsaw: Warsaw University of Life Sciences (SGGW).

Rosa, A. (2012) "Aktywność banków spółdzielczych w Polsce na tle wybranych europejskich spółdzielczych grup bankowych" [The activity of cooperative banks in Poland compared to selected European cooperative banking groups] in I. Pyka and J. Cichorska (eds) Finanse w niestabilnym otoczeniu - dylematy $i$ wyzwania. Bankowość [Finance in an unstable environment - dilemmas and challenges. Banking]. Academic Papers of the Katowice University of Economics No. 105. Katowice: Katowice University of Economics.

Siudek, T. (2008) "Wpływ kredytów rolniczych udzielanych przez banki spółdzielcze na rozwój rolnictwa w Polsce" [The impact of agricultural loans granted by cooperative banks on agricultural development in Poland] in Ekonomika i Organizacja Gospodarki $\dot{Z}$ ywnościowej [The economics and organisation of the food economy]. Academic Papers of the Warsaw University of Life Sciences No. 66. Warsaw: Warsaw University of Life Sciences (SGGW).

Swinnen, J. F. M. and Gow, H. R. (1999) "Agricultural Credit Problems and Polices During the Transition to a Market Economy in Central and Eastern Europe". Food Policy, Vol. 24, No. 1, http://dx.doi.org/10.1016/S0306-9192(98)00067-0.

Szambelańczyk, J. (2006) Banki spótdzielcze $w$ Polsce $w$ procesach zmian systemowych [Cooperative banks in Poland in a process of systemic change]. Poznań: Poznań University of Economics.

Wasilewski, M. and Mądra, M. (2009) "Determinanty kształtujące poziom finansowania gospodarstw rolniczych kapitałem obcym" [Determinants of the financing of farms by foreign capital] in J. Ostaszewski (ed.) Dylematy ksztattowania struktury kapitatu $w$ przedsiębiorstwie [Dilemmas in establishing the structure of capital in enterprises]. Warsaw: Warsaw School of Economics.

Wielicki, W. and Baum, R. (2010) "Problematyka zarządzania przedsiębiorstwami rolniczymi” [Agricultural enterprise management]. Life Sciences Yearbooks, Series G, Vol. 97, No. 3.

Zawadzka, D. (2007a) "Motywy wyboru kredytu kupieckiego przez mikro przedsiębiorstwa" [Motives for the choice of trade credit by micro-enterprises] in A. Bogus and M. Wypych (eds) Harmonizacja rynków finansowych i finansów przedsiębiorstw w skali narodowej $i$ europejskiej [The harmonisation of financial markets and enterprise finance at the national and European level]. Warsaw: Difin.

Zawadzka, D. (2007b) "Przesłanki kredytowania kontrahentów w obrocie gospodarczym" [Criteria for the provision of loans to contractors] in T. Dudycz and $\mathrm{L}$. Tomaszewicz Efektywność - rozważania nad istota i pomiarem [Efficiency - reflections on its essence and measurement]. Academic Papers of the Wrocław University of Economics No. 1183. Wrocław: Wrocław University of Economics.

Zawadzka, D. (2008a) "Ryzyko płatnicze w rozliczeniach wzajemnych małych przedsiębiorstw - w świetle wyników badań empirycznych” [Payment risk between 
small enterprises in light of empirical research] in B. Kołosowska (ed.) Wspótczesne Finanse. Stan i perspektywy rozwoju finansów przedsiębiorstw i ubezpieczeń [Modern finance. Current state and development prospects of enterprise finance and insurance]. Toruń: Nicolaus Copernicus University.

Zawadzka, D. (2008b) "Działalność małych przedsiębiorstw na obszarze Pomorza Środkowego" [The activity of small enterprises in the Middle Pomerania region] in D. Zawadzka (ed.) Pomorze Środkowe - spoteczeństwo, wieś, gospodarka. Wybrane problemy [Middle Pomerania - society, countryside, economy. Selected problems]. Koszalin: Polish Economic Society (PTE), Koszalin branch.

Zawadzka, D. (2009) Determinanty popytu małych przedsiębiorstw na kredyt handlowy. Identyfikacja i ocena [Determinants of small enterprises' demand for trade credit. Identification and assessment]. Poznań: Poznań University of Economics.

Zawadzka, D. (2010) Ryzyko wzajemnych rozliczeń przedsiębiorstw w Unii Europejskiej $w$ okresie kryzysu gospodarczego [Payment risk between enterprises in the European Union during the economic crisis]. Annales UMCS, Section H, Oeconomia, Vol. XLIV(2). Lublin: Marie-Curie Skłodowska University (UMCS).

Zawadzka, D. and Ardan, R. (2009) "Ocena czynników wpływających na prawdopodobieństwo skorzystania przez małe przedsiębiorstwa ze skonta w kredycie kupieckim" [Assessment of factors affecting the probability of small businesses using discounts on trade credit] in B. Bernaś (ed.) Zarzadzanie finansami firm - teoria i praktyka [Managing enterprise finance - theory and practice]. Wrocław: Wrocław University of Economics Press.

Ziętara, W. (2009) "Miary wielkości gospodarstw i przedsiębiorstw rolniczych" [Measuring the size of farms and agricultural enterprises]. Life Sciences Yearbooks, Series G, Vol. 96, No. 4.

\section{Abstract}

\section{Ryzyko kredytu handlowego w działalności przedsiębiorstw rolniczych regionu Pomorza Środkowego}

Celem badań zaprezentowanych w artykule jest ocena ryzyka związanego z udzielaniem kredytu handlowego w grupie przedsiębiorstw rolniczych na przykładzie podmiotów zlokalizowanych w regionie Pomorza Środkowego. Badanie dotyczące oceny ryzyka kredytowania kontrahentów w sektorze rolnym przebiegało wieloetapowo. W pierwszej kolejności dokonano charakterystyki badanej próby przedsiębiorstw, ze szczególnym uwzględnieniem skutków podejmowanych przez nie decyzji finansowych. W dalszej części przedstawiono cechy stosowanej polityki kredytu handlowego. Skoncentrowano się na ocenie skłonności do odraczania terminów płatności odbiorcom oraz charakterystyce stosowanych opustów cenowych. Pomiar ryzyka kredytowania kontrahentów oparto na wskaźniku udziału utraconych przychodów ze sprzedaży z tytułu braku spłaty zobowiązań w przedsiębiorstwie rolniczym w wyniku udzielonego odbiorcy kredytu handlowego w stosunku do wartości przychodów ogółem ze sprzedaży.

Słowa kluczowe: kredyt handlowy, ryzyko, przedsiębiorstwo rolnicze, Pomorze Środkowe. 